\title{
PENAHANAN TERHADAP ANAK YANG MELAKUKAN TINDAK PIDANA DI TINGKAT PENGADILAN TINGGI DI PENGADILAN TINGGI BANDA ACEH
}

\author{
Said Rizal, Yusriando, Mahyaya \\ Fakultas Ilmu Hukum, Universitas Prima Indonesia ${ }^{1,2}$ \\ Fakultas Hukum Universitas Muhammadyah Aceh ${ }^{3}$ \\ Jalan Skip, Simpang Sikmabing, Medan, Sumatera Utara \\ Email : saidrizal@unprimdn.ac.id
}

\begin{abstract}
ABSTRAK
Berdasarkan ketentuan Pasal 1 angka 21 KUHAP, penegak hukum seperti Penyidik, Penuntut Umum, atau Hakim di tingkat Pengadilan Negeri atau Pengadilan Tinggi mempunyai wewenang untuk melakukan penahanan, dalam hal serta menurut cara yang di atur dalam undang-undang ini. Terhadap anak, berdasarkan Pasal 16 ayat (3) UndangUndang Nomor 23 tahun 2002 tentang Perlindungan Anak, penangkapan, penahanan, atau tindak pidana penjara anak hanya dilakukan apabila sesuai dengan hukum yang berlaku dan hanya dapat dilakukan sebagai upaya terakhir. Dalam prakteknya masih banyak kasus-kasus anak yang melakukan tindak pidana yang ditahan oleh Hakim Pengadilan Tinggi Banda Aceh. Tujuan penulisan skripsi ini adalah untuk menjelaskan tentang pertimbangan Hakim untuk melakukan penahanan terhadap anak yang bermasalah dengan hukum di tingkat Pengadilan Tinggi Banda Aceh, dan dampak penahanan terhadap anak pelaku tindak pidana yang bermasalah dengan hukum. Data dalam penulisan skripsi ini diperoleh melalui penelaahan kepustakaan dengan cara mempelajari buku-buku teks, peraturan perundang-undangan, jurnal dan hasil-hasil penelitian, penelitian lapangan dengan cara mewawancarai responden dan imforman yang terkait dalam penanganan masalah anak terhadap anak yang berhadapan dengan hukum. Hasil penelitian di Pengadilan Tinggi Banda Aceh menunjukkan, maka pertimbangan Hakim melakukan penahanan terhadap anak yang bermasalah dengan hukum, yaitu menimbulkan adanya kekhawatiran tersangka atau terdakwa melarikan diri, merusak atau menghilangkan barang bukti atau mengulangi tindak pidana, dan kepentingan anak atau kepentingan masyarakat. Namun dampak penahanan, staf lembaga bantuan hukum dan Akademisi anak mengatakan, penahanan kepada anak pelanggar hukum berdampak buruk, anak akan mendapat ancaman kekerasan di tahanan baik oleh petugas atau tahanan lain. Si anak akan rentan terhadap pelecehan seksual oleh tahanan lain.
\end{abstract}

Kata Kunci : hukum. Pidana, seksusal, kekerasan, Anak

ABSTRACT

Based on the provisions of Article 1 number 21 of the Criminal Procedure Code, law enforcers such as Investigators, Public Prosecutors, or Judges at the District Court or High Court level have the authority to make detention, in terms of and according to the method regulated in this law. Against children, based on Article 16 paragraph (3) of Law Number 23 of 2002 concerning Protection of Children, arrest, detention, or a criminal offense for juvenile prisons is only carried out in accordance with applicable law and can only be done as a last resort. In practice there are still many cases of children who commit crimes held by the Banda Aceh High Court Judge. The purpose of writing this thesis is to explain the Judge's consideration to detain a child who is in trouble with the law at the Banda Aceh High Court level, and the impact of detention on a child who has a criminal offense who has problems with the law. The data in writing this thesis was obtained through a literature review by studying text books, legislation, journals and research results, field research by interviewing respondents and informants related to handling children's problems with children in conflict with the law. The results of the research in the Banda Aceh High Court showed that the Judges considered detaining children who had problems with the law, which caused the fear of a suspect or defendant fleeing, damaging or eliminating evidence or repeating a crime, and the interests of children or the interests of the community. However, the impact of detention, staff of legal aid agencies and child academics said that detention of lawbreakers had a bad impact, children would be threatened with violence in detention by officers or other detainees. The child will be vulnerable to sexual harassment by other prisoners.

Keywords: law. Criminal, sexual, violence, child 


\section{PENDAHULUAN}

Berdasarkan ketentuan Pasal 1 angka 21 KUHAP, semua instansi penegak hukum, penyidik atau penuntut umum atau hakim mempunyai wewenang untuk melakukan penahanan, dalam hal serta menurut cara yang di atur dalam Undang-Undang ini. Juga dari ketentuan tersebut telah diseragamkan istilah tindakan penahanan. Tidak dikacaukan lagi dengan berbagai ragam istilah seperti yang dulu dalam HIR, yang membedakan dan mencampur aduk antara penangkapan, penahanan sementara dan tahanan sementara, yang dalam peristilahan belanda disebut de verdachte aan te houden Pasal 60 ayat (1) HIR, yang berarti menangkap tersangka, dan untuk menahan sementara digunakan istilah voorlopig (Pasal 62 ayat (1) HIR). Serta untuk perintah penahanan yang dimaksud Pasal 83 HIR dipergunakan istilah zijin gevangen houding bevelen. 1

Pada perinsipnya penahanan adalah perampasan kebebasan bergerak seseorang yang seharusnya dihormati dan dilindungi oleh negara. Namun penahanan yang dilakukan terhadap tersangka/terdakwa oleh pejabat yang berwenang di batasi oleh hak-hak tersangka/terdakwa dan perturan-praturan secara limitatif sesuai dengan ketentuanketentuan yang ada di KUHAP. Pihak yang berwenang melakukan penahanan dalam berbagai tingkatan antara lain :Pada tahap penyidikan, yang berwenang melakukan penahanan penyidik, Tahap penuntutan, yang berwenang penuntut umum dan Tahap pemeriksaan, yang berwenang menahan adalah hakim

Putusan Hakim akan mempengaruhi kehidupan anak sebagai pelaku tindak pidana. Oleh sebab itu Hakim harus yakin bahwa putusan yang akan diambil akan dapat menjadi salah satu dasar hukum yang kuat untuk

\footnotetext{
M. Yahya Harahap, Pembahasan Pemasalahan dan Penerapan KUHAP, Sinar Grafika, Jakarta, 2003, hlm 105.
}

mengembalikan dan mengantar anak menuju masa depan yang lebih baik dan untuk mengembangkan dirinya sebagai warga yang bertanggungjawab bagi keluarga, bangsa dan negara. Hal ini harus diperhatikan oleh hakim sebagai aparat penegak hukum dalam menangani kasus tindak pidana yang dilakukan oleh anak. Oleh karena itu dalam melaksanakan pemeriksaan terhadap anak sebagai pelaku tindak pidana, haruslah diperhatikan tentang tujuan peradilan anak yaitu melakukan koreksi dan rehabilitasi, sehingga anak dapat kembali ke kehidupan yang normal dan mandiri demi potensi masa depannya. 2

Selain penangkapan, KUHAP juga mengenal panahanan. Istilahnya cukup sederhana tanpa embel-embel kata sementara. KUHAP hanya mengenal istilah penahanan, yang wewenangnya diberikan kepada semua instansi penegak hukum yaitu kepolisian, kejaksanaan dan kehakiman. Masing-masing mempunyai batas waktu yang ditentukan secara limitatif. Sehubungan dengan penetapan waktu yang sangat terbatas bagi setiap instansi merupakan hal baru yang sangat menggembirakan dalam dunia penegakan hukum. Sebab dengan pembatasan yang limitatif tersebut, tercipta tegaknya kepastian hukum dalam penahanan. Tidak lagi seperti pada masa HIR, yang memberi keleluasaan bagi Ketua Pengadilan Negeri untuk memperpanjang penahanan tanpa batas, sehingga sering terjadi perpanjangan tahanan yang melebihi satu atau dua tahun. Benarbenar tak ada kepastian hukum bagi seorang tersangka atau yang ditahan.3

Prinsip proses hukum yang adil dalam asas-asas penegakan hukum di dalam KUHAP

\footnotetext{
${ }^{2}$ Sri Widowati Soekanto, Anak dan Wanita Dalam Hukum, LP 3 ES, Jakarta, 1984, hlm13.

${ }^{3}$ Andi Hamzah, Pengantar Hukum Acara Pidana Indonesia, Ghalia Indonesia, Jakarta, 1984, hlm. 23
} 
merupakan penjabaran dari asas pengayoman dalam Undang-undang Nomor 48 Tahun 2009 tentang Pokok-pokok Kekuasaan Kehakiman, Lembaran Negara tahun 2009. Hal itu berarti bahwa latar belakang pentingnya penahanan sebagai salah satu upaya paksa yang penting dalam proses peradilan pidana, adalah dalam konteks pengayoman bagi masyarakat umum (publik), korban tindak pidana dan juga bagi tersangka/terdakwa itu sendiri. Bertolak dari pendapat tersebut dapat dikatakan bahwa salah satu asumsi dasar penahanan adalah negara merasa berkewajiban membina warganya termasuk mereka yang masuk ke dalam proses peradilan pidana. 4

Secara harfiah, Peradilan Anak terdiri dari dua kata yaitu kata peradilan dan anak. Menurut kamus Bahasa Indonesia, peradilan berarti segala sesuatu mengenai pengadilan. Jadi peradilan merupakan peristiwa atau kejadian/hal-hal yang terjadi mengenai perkara di pengadilan. Secara sempit, peradilan adalah hal-hal yang menyangkut hukum acara yang hendak mempertahankan materiilnya. Sedangkan secara luas adalah kejadiankejadian/hal-hal yang terjadi dengan suatu perkara termasuk proses penerapan hukum acara dalam mempertahankan materiilnya.

Berdasarkan hasil penelitian di Pengadilan Tinggi Banda Aceh, dengan mengambil data terhitung dari bulan JanuariDesember tahun 2013, memperlihatkan adanya penahanan anak yang melakukan tindak pidana oleh Pengadilan Tinggi Banda Aceh berjumlah 10 orang dan 9 orang anak yang tidak ditahan, jumlah ini memperlihatkan masih banyak anak-anak yang melakukan tindak pidana yang ditahan oleh Pengadilan Tinggi Banda Aceh.

Berdasarkan uraian tabel diatas memperlihatkan, penetapan hakim Pengadilan Tinggi Banda Aceh dari bulan Januari sampai Desember 2013 adanya anak yang ditahan dan anak yang tidak ditahan oleh Pengadilan

${ }^{4}$ J.E Sahetapy, "Hukum dalam Konteks Sosial Politik dan Budaya". 11 Analisis, Tahun XXII No. 1 Januari - Februari 1993. Hlm. 54
Tinggi Banda Aceh berjumlah 10 orang anak yang ditahan, dan anak yang tidak ditahan berjumlah 9 orang.

Namun demikian sering kali pihak anak yang dirugikan karena mengingat bahwa anak tidak dapat menuntut haknya sebagaimana orang dewasa,sehingga anak yang dapat memperjuangkan haknya hanya orang tua dan lembaga-lembaga anak.

Berdasarkan latar belakang masalah diatas, maka dapat dirumuskan permasalahannya sebagai berikut : Apakah Pertimbangan Hakim Pengadilan Tinggi melakukan penahanan terhadap anak? Dan Apakah dampak penahanan bagi anak pelaku tindak pidana?

\section{METODE PENELITIAN}

1. Defenisi Oprasional Variabel

a. Menurut Pasal 1 Undang-Undang Pelindungan Anak menyebutkan, "anak adalah seseorang yang belum berusia 18 (delapan belas) tahun, termasuk anak yang masih dalam kandungan".

b. Tindak Pidana adalah perbuatan melakukan atau tidak melakukan sesuatu yang oleh peraturan perundang-undangan dinyatakan sebagai perbuatan yang dilarang dan diancam dengan pidana.

c. Berdasarkan Pasal 1 ayat (21) KUHAP, "Penahanan adalah penempatan tersangka atau terdakwa di tempat tertentu oleh penyidik atau penuntut umum atau hakim dengan penetapanya, dalam hal menurut cara yang diatur dalam undang-undang ini".

2. Lokasi Dan Populasi Penelitian

Lokasi penelitian adalah Wilayah Hukum Pengadilan Tinggi Banda Aceh. Sedangkan populasi dari penelitian ini adalah Hakim Pengadilan Tinggi Banda Aceh, Akademisi bidang anak, Staf Bantuan Hukum anak.

3. Cara Pengambilan Sampel 
Cara pengambilan sampel dilakukan dengan cara purposive sampling. Sampel diambil dari semua populasi yang ada guna mewakili seluruh pihak yang terlibat. Adapun sampel terdiri dari :

Responden :

a. Hakim Tinggi pada Pengadilan Tinggi Banda Aceh yang menangani kasus anak 1 (satu) Orang

b. Staf Bantuan Hukum Anak 1 (satu) orang

Informan :

a. Hakim Tinggi pada Pengadilan Tinggi Banda Aceh 1(satu) orang

b. Akademisi Bidang Anak 1 (satu) orang

4. Cara Pengumpulan Data

Untuk memproleh data yang diperlukan dalam skripsi ini dilakukan penelitian kepustakaan (library research) yaitu dengan membaca dan mempelajari peraturan perundang-undangan, literaturliteratur, jurnal hukum serta pendapat para sarjana yang relevan dengan penulisan skripsi ini. Sedangkan untuk melengkapi juga dilakukan penelitian lapangan (field research ) yang dilakukan dengan cara mewawancarai responden.

5. Cara Analisis Data

Dari keseluruhan data yang diperoleh baik dari penelitian kepustakaan maupun penelitian lapangan dianalisis dengan mengunakan pendekatan kualitatif sehinga menghasilkan sebuah karya tulis berbentuk skripsi.

\section{HASIL DAN PEMBAHASAN}

A. Pertimbangan Hakim Tinggi Melakukan Penahanan Terhadap Anak

Menanggapi dan menangani proses peradilan anak yang terlibat tindak pidana, maka hal yang pertama yang tidak boleh dilupakan adalah melihat kedudukannya sebagai anak dengan semua sifat dan ciricirinya yang khusus, dengan demikian orientasi adalah bertolak dari konsep perlindungan terhadap anak dalam proses penangannya sehingga hal ini akan berpijak pada konsep kejahteraan anak dan kepentingan anak tersebut. Penanganan anak dalam proses hukumnya memerlukan pendekatan, pelayanan, perlakuan, perawatan serta perlindungan yang khusus bagi anak dalam upaya memberikan perlindungan hukum terhadap anak yang berhadapan dengan hukum.

Namun pertimbangan hakim terkait dengan penahanan, penahanan tahap banding terhadap anak berbeda dengan penahanan terhadap orang dewasa yaitu dilakukan hanya berlaku paling lama 15 (lima belas) hari dan apabila belum selesai, atas permintaan hakim tinggi dapat diperpanjang oleh Ketua Pengadilan Tinggi yang berwenang untuk paling lama 30 (tiga puluh) hari. Dalam waktu 30(tiga puluh) hari, apabila jangka waktu tersebut dilampaui maka tersangka harus dikeluarkan dari tahanan demi hukum. Perbedaan antara penahanan terhadap anak dengan penahanan orang dewasa terletak di jangka waktu penahanan dan perpanjangan penahanan apabila proses penyidikan belum selesai. Penahanan tahap pertama bagi orang dewasa 30 (tiga puluh) hari dan dapat diperpanjang paling lama 60 (enam puluh) hari. Disamping itu penahanan terhadap anak dilaksanakan di tempat khusus untuk anak yakni lembaga penempatan anak sementara (LPAS) atau lembaga Penyelenggaraan kesejahteraan social (LPKS) apabila belum terdapat LPAS.

Penahanan yang dilakukan dengan sungguh-sungguh hakim mempertimbangkan kepentingan anak. Hakim tinggi yang melakukan tindakan penahanan, harus terlebih dahulu mempertimbangkan dengan matang akibat dari tindakan penahanan, dari segi kepentingan anak, seperti pertumbuhan dan 
perkembangan anak baik fisik, mental maupun sosial.

Selain itu dipertimbangkan dengan kepentingan masyarakat, Syarat subjektif diletakkan pada keadaan yang menimbulkan adanya kekhawatiran tersangka atau terdakwa melarikan diri, merusak atau menghilangkan barang bukti atau mengulangi tindak pidana. Semua keadaan yang mengkhawatirkan ini adalah keadaan yang meliputi subjektifitas tersangka atau terdakwa. Pejabat yang menilai adanya keadaan misalnya dengan ditahannya tersangka masyarakat menjadi aman dan tentram.

Pejabat yang menilai adanya keadaan yang mengkhawatirkan itu, juga bertitik tolak pada penilaian subjektif. Dalam hal ini ada dua segi subjektif yakni segi subjektif tersangka atau terdakwa, yang dinilai secara subjektif oleh penegak hukum yang bersangkutan. Sangat sulit menilai secara objektif adanya niat tersangka atau terdakwa untuk melarikan diri, merusak atau menghilangkan barang bukti atau mengulangi tindak pidana. Secara teoritis bisa dibuat suatu konstruksi yang dapat menggambarkan keadaan yang mengkhawatirkan. Misalnya, tersangka diketahui membeli tiket pesawat ke luar negeri atau tersangka menyiapkan perkakas atau alat yang serasi untuk mengulangi tindak pidana.

Namun demikian dalam konkreto sangat sulit menilai suatu keadaan yang menghawatirkan, dan keadaan mengkhawatirkan itu lebih erat ukurannya dengan penilaian subjektif orang yang merasa khawatir itu. Berbeda dengan syarat subkjektif yang menitik beratkan pada penilaian subjektif pejabat yang berwenang, Pasal 21 ayat (4) menentukan tindak pidana yang pembuatnya dapat ditahan. Ketentuan ini merupakan syarat objektif penahanan karena hanya tindak pidana yang ancaman pidananya lima tahun atau lebih dan tindak pidana yang ancaman pidananya tidak sampai lima tahun tetapi disebut secara khusus segala tindak pidana yang pembuatnya dapat ditahan.
Pejabat yang berwenang melakukan penahanan tidak dapat menambah atau menafsirkan lain tindak pidana yang pembuatnya dapat ditahan, walaupun menurut penilaian subjektifinya, pembuat tindak pidana tersebut perlu ditahan. Syarat subjektif dan objektif berlaku juga terhadap mekanisme penahanan yang diatur dalam Undang-undang khusus seperti Undang-undang nomor 3 Tahun 1997 tentang Pengadilan Anak, Undangundang Nomor 26 Tahun 2000 tentang Pengadilan HAM. Penahanan menurut Undang-undang Nomor 3 Tahun 1997 tentang Pengadilan Anak, dilakukan terhadap anak yang diduga keras melakukan tindak pidana berdasarkan bukti permulaan yang cukup.

Namun dalam pelaksanaannya, pejabat yang berwenang melakukan penahanan harus memperhatikan syarat subjektif dan objektif sebagaimana dimaksud dalam Pasal 21 ayat (4) KUHAP. Selain itu, penahanan terhadap anak dilakukan setelah dengan sungguh-sungguh mempertimbangkan kepentingan anak dan atau kepentingan masyarakat. Hal ini sulit didalam penerapannya, sebab dalam mempertimbangkan kepentingan yang dilindungi dengan melakukan penahanan, tidak mudah dan menyulitkan pihak penyidik yang melakukan tindakan penahanan. Dalam tindakan penahanan, penyidik seharusnya melibatkan pihak yang berkompeten, seperti pembimbing kemasyarakatan, psikolog, kriminolog, dan ahli lain yang diperlukan, sehingga penyidik anak tidak salah mengambil keputusan dalam melakukan penahanan.5

Di sisi lain, pertimbangan hakim Pengadilan Tinggi dalam melakukan penahanan terhadap pelaku tindak pidana atau anak yang bermasalah dengan hukum, contohnya dalam kasus narkoba, dengan melakukan penahanan terhadap anak tersebut akan terungkapnya pelaku tindak pidana yang

\footnotetext{
${ }^{5}$ Eddy Risdiyanto SH, (Hakim Tinggi), wawancara, 20 maret 2014
} 
lain atau otak pelaku tindak pidana narkoba tersebut.6

Berdasarkan hasil penelitian di Pengadilan Tinggi Banda Aceh, dengan mengambil data terhitung dari bulan JanuariDesember tahun 2013, memperlihatkan adanya penahanan anak yang melakukan tindak pidana oleh Pengadilan Tinggi Banda Aceh berjumlah 10 orang dan 9 orang anak yang tidak ditahan.

\footnotetext{
${ }^{6}$ Dediek Budi Utomo SH, (Hakim Tinggi)

wawancara, 01 april r2014
} 
Tabel 1 Jumlah data anak sebagai pelaku tindak pidana yang ditahan oleh Pengadilan Tinggi Banda Aceh Tahun 2013

\begin{tabular}{cccc}
\hline No & Nomor Tahanan PT BNA & Nama Terdakwa & Penetapan Hakim \\
\hline 1 & 170/Pen.Pid/2013/PT-BNA & ED & Ditahan \\
2 & 237/Pen.Pid/2013/PT-BNA & HH & Ditahan \\
3 & 269/Pen.Pid/2013/PT-BNA & HS & Ditahan \\
4 & 294/Pen.Pid/2013/PT-BNA & JJ & Ditahan \\
5 & 312/Pen.Pid/2013/PT-BNA & ZL & Ditahan \\
6 & 346/Pen.Pid/2013/PT-BNA & EA & Ditahan \\
7 & 388/Pen.Pid/2013/PT-BNA & MS & Ditahan \\
8 & 405/Pen.Pid/2013/PT-BNA & KF & Ditahan \\
9 & 631/Pen.Pid/2013/PT-BNA & KI & Ditahan \\
10 & 642/Pen.Pid/2013/PT-BNA & 10 (sepuluh) Anak yang ditahan \\
\hline \multicolumn{5}{c}{ Jumlah }
\end{tabular}

Sumber : Pengadilan Tinggi Banda Aceh, 2013

Tabel 2 Jumlah Data anak sebagai pelaku tindak pidana yang tidak ditahan oleh Pengadilan Tinggi Banda Aceh Tahun 2013

\begin{tabular}{llcc}
\hline No & Nomor Perkara PT BNA & Nama Terdakwa & Penetapan Hakim \\
\hline 1 & 15/Pid/2013/PT BNA & MF & Tidak ditahan \\
2 & 02/Pid/2013/PT BNA & HR & Tidak ditahan \\
3 & $96 /$ Pid/2013/PT BNA & HH & Tidak ditahan \\
4 & $97 / \mathrm{Pid} / 2013 /$ PT BNA & HS & Tidak ditahan \\
5 & $107 / \mathrm{Pid} / 2013 /$ PT BNA & SF & Tidak ditahan \\
6 & $118 /$ Pid/2013/PT BNA & HR & Tidak ditahan \\
7 & $124 /$ Pid/2013/PT BNA & ZF & Tidak ditahan \\
8 & 150/Pid/2013/PT BNA & KA & Tidak ditahan \\
9 & $178 /$ Pid/2013/PT BNA & DN & Tidak ditahan \\
\hline & Jumlah & 9 (sembilan) Anak yang tidak ditahan \\
\hline
\end{tabular}

Sumber : Pengadilan Tinggi Banda Aceh, 2013

Berdasarkan uraian tabel diatas memperlihatkan, penetapan hakim Pengadilan Tinggi Banda Aceh dari bulan Januari sampai Desember 2013 adanya anak yang ditahan dan anak yang tidak ditahan oleh Pengadilan Tinggi Banda Aceh berjumlah 10 orang anak yang ditahan, dan anak yang tidak ditahan berjumlah 9 orang.

Namun demikian sering kali pihak anak yang dirugikan karena mengingat bahwa anak tidak dapat menuntut haknya sebagaimana orang dewasa,sehingga anak yang dapat memperjuangkan haknya hanya orang tua dan lembaga-lembaga anak.

Untuk mengetahui lebih jelas tentang penahanan dan masa perpanjangan penahanan terhadap anak sebagai pelaku tindak pidana di Pengadilan Tinggi Banda Aceh, dibawah ini menjelaskan penetapan hakim sebagai berikut:

1) Dalam penetapannya Nomor : 178/Pen.Pid/2013/Pt-Bna.

Ketua Pengadilan Tinggi/Tipikor Banda Aceh. Membaca surat Perkara Banding Pidana Akta Nomor: W1.U8/297/HK.01/IV/2013, Perkara Nomor : 18/Pid.B/2013/PN-MBO, atas nama terdakwa: Nama lengkap, ED. Umur, 16 Tahun. Jenis kelamin, Lakilaki. Kebangsaan, Indonesia. Agama, Islam. Pekerjaan, Ikut Orang Tua. 
Terdakwa telah ditahan berdasarkan Surat Perintah/Penetapan Penahanan :

1. Penyidik, sejak tanggal 08 Januari 2013 s.d tanggal 27 Januari 2013

2. Perpanjangan oleh Penuntut Umum, sejak tanggal 28 Januari 2013 s.d tanggal 06 Pebruari 2013

3. Penuntut Umum, sejak tanggal 06 Pebruari 2013 s.d tanggal 15 Pebruari 2013.

4. Mejelis Hakim Pengadilan Negeri Meulaboh, sejak tanggal 15 Pebruari 2013 s.d tanggal 02 Maret 2013;

5. Perpanjangan oleh Ketua Pengadilan Negeri Meulaboh, sejak tanggal 03 Maret 2013 s.d tanggal 01 April 2013

6. Penetapan Penahanan oleh Wakil Ketua Pengadilan Tinggi/Tipikor Banda Aceh, sejak tanggal 03 April 2013 s.d tanggal 17 April 2013

Menimbang, bahwa terdakwa telah ditahan melakukan tindak pidana yang diatur dalam Dakwaan, primair Pasal 81 ayat (1) UU RI No.23 Tahun 2002 tentang Perlindungan Anak, Jo. UU RI No.3 Tahun 1997 tentang Peradilan Anak, subsidair Pasal 81 ayat (1) UU RI No.23 Tahun 2002 tentang Perlindungan Anak, Jo. Undang-Undang Republik Indonesia Nomor 3 Tahun 1997 tentang Peradilan Anak.

Menimbang, bahwa penetapan Hakim Pengadilan Tinggi/Tipikor tersebut diatas, akan habis/tidak berlaku lagi pada tanggal 18 April 2013. Menimbang, bahwa guna kepentingan pemeriksaan dipandang perlu memperpanjang waktu penahanan atas terdakwa tersebut paling lama 30 (tiga puluh) hari.

Memperhatikan Pasal 48 ayat (3) Undang-Undang Republik Indonesia Nomor 3 Tahun 1997 tentang Peradilan Anak, Jo. Pasal 21 ayat (4) KUHAP (Undang-Undang Republik Indonesia.
Nomor. 8 Tahun 1981). Memperpanjang waktu penahanan terdakwa ED dalam Rumah Tahanan Negara di Meulaboh paling lama 30 (tiga puluh) hari, terhitung sejak tanggal 18 April 2013 s.d tanggal 17 Mei 2013. Memerintahkan agar kepada terdakwa dan keluarganya selekas mungkin diberikan sehelai tembusan dari penetapan ini. ${ }^{7}$

2) Dalam Penetapan Penahanan yang ke dua terhadap anak sebagai pelaku tindak pidana menjelaskan dalam Perkara Nomor :238/Pen.Pid/2013/PT-BNA.

Ketua Pengadilan Tinggi/Tipikor Banda Aceh.

Membaca surat perkara banding pidana Akta Nomor : W1.U15/327/HN.01.1/V/2013, perkara Nomor : 54/Pid.A/2013/PN-TKN, atas terdakwa: Nama, HH. Umur, 17 Tahun. Jenis kelamin, Laki-laki. Kebangsaan, Indonesia. Tempat tinggal, Kampung Bale Simpang Tiga, Kec. Bukit, Kab. Bener Meriah. Aga ma Islam.

Terdakwa telah ditahan berdasarkan Surat Perintah/Penetapan Penahanan :

1. Penyidik, sejak tanggal 10 Pebruari 2013 s.d tanggal 01 Maret 2013

2. Perpanjangan oleh Kejari, sejak tanggal 02 Maret 2013 s.d tanggal 11 Maret 2013

3. Penuntut Umum, sejak tanggal 11 Maret 2013 s.d tanggal 20 Maret 2013

4. Mejelis Hakim Pengadilan Negeri Takengon, sejak tanggal 20 Maret 2013 s.d tanggal 04 April 2013

5. Perpanjangan oleh Ketua Pengadilan Negeri Takengon, sejak tanggal 05 April 2013 s.d tanggal 05 Mei 2013

6. Penetapan Penahanan oleh Wakil Ketua Pengadilan Tinggi/Tipikor Banda Aceh, sejak tanggal 03 Mei 2013 s.d tanggal 17 Mei 2013.

\footnotetext{
${ }^{7}$ Sumber data Pengadilan Tinggi Banda Aceh Nomor Perkara: 178/Pen.Pid/2013/PT-BNA
} 
Menimbang, bahwa terdakwa telah ditahan melakukan tindak pidana yang diatur dalam Dakwaan : Pasal 363 ayat (1) ke-4 dan ke-5 KUHP, Jo. Undang-Undang No.3 Tahun 1997 tentang Pengadilan Anak. Menimbang, bahwa penetapan Hakim Pengadilan Tinggi/Tipikor Banda Aceh tersebut diatas, akan habis/tidak berlaku lagi pada tanggal 18 Mei 2013.

Menimbang, bahwa guna kepentingan pemeriksaan dipandang perlu memperpanjang waktu penahanan atas terdakwa tersebut paling lama 30 (tiga puluh) hari. Memperhatikan Pasal 48 ayat (3) Undang-Undang Republik Indonesia Nomor 3 Tahun 1997 tentang Pengadilan Anak, Jo. Pasal 21 ayat (4) KUHAP (Undang-Undang No.8 Tahun 1981). Menetapkan, memperpanjang waktu penahanan terdakwa HENDRI HAJIKA Bin HASBULAH dalam Rumah Tahanan Negara di Takengon paling lama 30 (tiga puluh) hari, terhitung sejak tanggal 18 Mei 2013 s.d tanggal 16 Juni $2013 .{ }^{8}$

3) Dalam Penetapan Penahanan yang ke tiga terhadap anak sebagai pelaku tindak pidana menjelaskan dalam Perkara Nomor :270/Pen.Pid/2013/PT-BNA.

Ketua Pengadilan Tinggi/Tipikor Banda Aceh.

Membaca surat perkara banding pidana Akta Nomor : W1.U12/1030/HK.01/IV/2013, perkara Nomor : 71/Pid.B/2013/PN-LSK, atas terdakwa:Nama, HS. Umur, 16 Tahun. Jenis kelamin, Laki-laki. Kebangsaan,Indonesia. Tempat tinggal, Dusun Batee Timoh, Desa Krueng Geukeuh, Kec. Dewantara, Kab. Aceh Utara. Agama, Islam.

\footnotetext{
${ }^{8}$ Sumber data di Pengadilan Tinggi Banda Aceh Nomor Perkara: 238/Pen.Pid/2013/PT-BNA
}

Nama, EA. Umur, 16 Tahun. Jenis kelamin, Laki-laki. Kebangsaan, Indonesia. Tempat tinggal, Dusun Batee Timoh, Desa Krueng Geukeuh, Kec. Dewantara, Kab. Aceh Utara. Agama, Islam. Pekerjaan,Pelajar.

Terdakwa telah ditahan berdasarkan Surat Perintah/Penetapan Penahanan :

1. Penyidik, sejak tanggal 15 Pebruari 2013 s.d tanggal 06 Maret 2013;

2. Perpanjangan oleh Penuntut Umum, sejak tanggal 07 Maret 2013 s.d tanggal 16 Maret 2013;

3. Penuntut Umum, sejak tanggal 15 Maret 2013 s.d tanggal 24 Maret 2013;

4. Hakim Pengadilan Negeri Lhoksukon, sejak tanggal 20 Maret 2013 s.d tanggal 03 April 2013;

5. Perpanjangan oleh Ketua Pengadilan Negeri Lhoksukon, sejak tanggal 04 April 2013 s.d tangfggal 03 Mei 2013;

6. Penetapan Penahanan oleh Wakil

Ketua Pengadilan Tinggi/Tipikor Banda Aceh, sejak tanggal 29 April 2013 s.d tanggal 13 Mei 2013.

Menimbang, bahwa terdakwa telah ditahan melakukan tindak pidana yang diatur dalam dakwaan primer Pasal 365 ayat (2) ke-2 dan ke-4 KUH Pidana, Jo. Undang-Undang Republik Indonesia Nomor 3 Tahun 1997 tentang Peradilan Anak. Subsider, Pasal 365 ayat (2) ke-2 dan ke-4 KUH Pidana, Jo. UU RI No.3 Tahun 1997 tentang Peradilan Anak.

Menimbang, bahwa penetapan Hakim Pengadilan Tinggi/Tipikor tersebut diatas akan habis/tidak berlaku lagi pada tanggal $\underline{14}$ Mei 2013. Menimbang, bahwa guna kepentingan pemeriksaan dipandang perlu memperpanjang waktu penahanan atas terdakwa tersebut paling lama 30 (tiga puluh) hari. Memperhatikan Pasal 48 ayat (3) Undang-Undang No.3 Tahun 
1997 tentang Pengadilan Anak, Jo. Pasal 21 ayat (4) KUHAP (UU R.I. No.8 Tahun 1981), Memperpanjang waktu penahanan terdakwa I. HERI SAPUTRA Bin M. YUSUF dan terdakwa II. EFAN ALFATRA Bin RUSLI dalam Rumah Tahanan Negara di Lhoksukon paling lama 30 (tiga puluh) hari, terhitung sejak tanggal 14 Mei 2013 s.d tanggal 12 Juni 2013. ${ }^{9}$

4) Dalam Penetapan perintah penahanan oleh Hakim Pengadilan Tinggi/Tipikor Banda Aceh. (Pasal 48 ayat (1), ayat (2) Undang-Undang Republik Indonesia No.3 Tahun 1997 tentang Peradilan Anak). Nomor : 312/Pen.Pid/2013/PTBNA. Hakim Pengadilan Tinggi/Tipikor Banda Aceh.

Membaca surat perkara banding pidana Akta Nomor : W1.U5/2128/HK.01/VI/2013, perkara Nomor : 131/Pid.B/2013/PN-SGI, atas terdakwa: Nama lengkap, ZUL. Tempat lahir, Medan, Sumatera Utara. Umur, 17 Tahun. Jenis kelamin, Laki-laki. Kebangsaa, Indonesia. Tempat, tinggal, Desa Blang Galang, Kec. Pidie, Kab. Pidie. Agama, Islam. Pekerjaan, Pelajar.

Terdakwa telah ditahan

berdasarkan Surat Perintah/Penetapan

Penahanan :

1. Penyidik, sejak tanggal 02 April 2013 s.d tanggal 21 April 2013

2. Perpanjangan oleh Kajari, sejak tanggal 22 April 2013 s.d tanggal 01 Mei 2013

3. Penuntut Umum, sejak tanggal $01 \mathrm{Mei}$ 2013 s.d tanggal 10 Mei 2013

4. Hakim Pengadilan Negeri Sigli, sejak tanggal 08 Mei 2013 s.d tanggal 22 Mei 2013
5. Perpanjangan Penahanan oleh Ketua Pengadilan Negeri Sigli, sejak tanggal 23 Mei 2013 s.d tanggal 21 Juni 2013

Menimbang, bahwa terdakwa telah ditahan melakukan tindak pidana yang diatur dalam Dakwaan Kesatu : Pasal 114 ayat (1) Undang Undang Republik Inndonesia No.35 Tahun 2009 tentang Narkotika Dan Kedua Pasal 111 ayat (1) UU RI No.35 Tahun 2009 tentang Narkotika.

Menimbang, bahwa bedasarkan surat laporan Ketua Pengadilan Negeri dalam perkara terdakwa tersebut telah dinyatakan putus dan menyatakan banding.

Menimbang, bahwa Penetapan Ketua Pengadilan Negeri tersebut di atas akan habis/tidak berlaku lagi pada tanggal 18 Juni 2013. Bahwa guna kepentingan pemeriksaan dipandang perlu untuk mengeluarkan Surat Perintah penahanan atas terdakwa tersebut. Memperhatikan Pasal 48 ayat (1), ayat (2) Undang-Uundang Republik Indonesia. Nomor 3 Tahun 1997 tentang Peradilan Anak, Jo. Pasal 21 ayat (4) KUHAP (Undang-Undang epublik Indonesia Nomor 8 Tahun 1981). Menetapkan, Memerintahkan untuk melakukan penahanan atas terdakwa ZULFIKAR BIN M. NASIR dalam Rumah Tahanan Negara di Sigli paling lama 15 (lima belas) hari sejak tanggal $\underline{18 \text { Juni } 2013}$ s.d tanggal $\underline{02}$ Juli 2013. ${ }^{10}$

\footnotetext{
${ }^{9}$ Sumber data di Pengadilan Tinggi Banda Aceh dengan Nomor Perkara:270 /Pen.Pid/2013/PTBNA
} 


\section{B. Dampak penahanan bagi anak pelaku tindak pidana}

Penyimpangan tingkah laku atau perbuatan hukum yang dilakukan oleh anak disebabkan oleh berbagai faktor, antara lain : adanya dampak negatif dari perkembangan pembangunan yang cepat, arus globalisasi di bidang komunikasi dan informasi, kemajuan ilmu pengetahuan dan teknologi serta perubahan gaya dan cara hidup sebagian orang tua, telah membawa perubahan sosial yang mendasar dalam kehidupan masyarakat yang sangat berpengaruh terhadap nilai dan perilaku anak. Selain itu anak yang kurang atau tidak memperoleh kasih sayang, asuhan, bimbingan dan pembinaan dalam pengembangan sikap, perilaku, penyesuaian diri, serta pengawasan dari orang tua, wali, atau orang tua asuh akan mudah terseret dalam arus pergaulan masyarakat dan lingkungannya yang kurang sehat dan merugikan perkembangan pribadinya.

Dalam menghadapi dan menanggulangi berbagai perbuatan dan tingkah laku anak nakal, perlu dipertimbangkan kedudukan anak dengan segala ciri dan sifatnya yang khas, yaitu bersifat labil, mudah terpengaruh, cenderung bersikap meniru terhadap lingkungan sekitar. Walaupun anak telah dapat menentukan sendiri langkah perbuatannya berdasarkan pikiran, perasaan dan kehendaknya, tetapi keadaan sekitarnya dapat mempengaruhi perilakunya. Oleh karena itu, dalam mengahadapi masalah anak nakal orang tua dan masyarakat sekelilingnya seharusnya lebih bertanggung jawab terhadap pembinaan, pendidikan dan pengembangan perilaku anak tersebut.

Hubungan antara orang tua dan anak merupakan suatu hubungan yang hakiki, baik hubungan psikologi maupun mental spiritualnya. Mengingat ciri dan sifat anak yang khas tersebut, maka dalam menjatuhkan pidana atau tindakan terhadap anak nakal diusahakan agar anak di maksud jangan dipisahkan dari orang tuanya. Apabila hubungan antara orang tua dan anak kurang baik, atau karena sifat perbuatannya sangat merugikan masyarakat sehingga perlu memisahkan anak dari orang tuanya, hendaklah tetap dipertimbangkan bahwa pemisahan tersebut semata-mata demi pertumbuhan dan perkembangan anak secara sehat dan wajar.

Perbuatan anak yang nyata-nyata bersifat "melawan hukum", dirasakan sangat mengganggu kehidupan masyarakat. Akibatnya, kehidupan masyarakat menjadi resah, perasaan tidak aman bahkan menjadi ancaman bagi usaha mereka. Oleh karena itu perlu perhatian terhadap usaha penanggulangan dan penanganannya, khususnya di bidang hukum pidana beserta hukum acaranya. Hal ini erat hubungannya dengan perlakuan khusus terhadap pelaku tindak pidana yang masih muda usianya, sebab adalah hak setiap anak untuk diperlakukan secara manusiawi, walaupun ia terlibat tindak pidana.

Akademisi bidang anak mengatakan, penahanan kepada anak yang bermasalah dengan hukum berdampak cukup besar terhadap anak, antara lain:

1. Anak akan mendapat ancaman kekerasan di tahanan baik oleh petugas atau tahanan lain.

2. Si anak akan rentan terhadap pelecehan seksual oleh tahanan lain. Ada beberapa kasus anak disodomi oleh tahanan lainnya.

3. Terjadi transfer keterampilan kejahatan dari tahanan lama kepada tahanan baru. Akibatnya, saat keluar dari tahanan, anak akan berubah menjadi pelaku kriminal.

4. Dengan di tahan, anak tidak bisa melanjutkan pendidikan atau suramnya masa depannya si anak.

Sebaiknya jika ada anak yang berhadapan dengan hukum, anak tetap dikembalikan kepada orang tuanya tidak perlu harus ditahan, kecuali orang tuanya tidak 
menerima keberadaan sianak dengan alasan tidak sanggup dibina dan dikhawatirkan mengulangi tindak pidana. Harapan kita kasusnya juga tidak perlu diteruskan, cukup didamaikan atau ganti kerugian," paparnya. Kecuali tidak ada upaya lain memang anak harus ditahan, baru di ambil upaya terakhir (ultimum remedium). Semua konsep tentang anak yang berhadapan dengan hukum ini tidak lepas dari undang-undang dan konvensi hak anak antara lain:

1. Undang-Undang No 39 Tahun 1999 Tentang Hak Asasi Manusia. Pasal 58 ayat (1). Setiap anak berhak untuk mendapatkan perlindungan hukum dari segala bentuk kekerasan fisik atau mental, penelantaran, perlakuan buruk, dan pelecehan seksual selama dalam pengasuhan orang tua atau walinya, atau pihak lain manapun yang bertanggung jawab atas pengasuhan anak tersebut.

2. Undang-Undang Republik Indonesia Nomor 23 Tahun 2002 Tentang Perlindungan Anak Pasal 1 ayat (2). Perlindungan anak adalah segala kegiatan untuk menjamin dan melindungi anak dan hak-haknya agar dapat hidup, tumbuh, berkembang, dan berpartisipasi, secara optimal sesuai dengan harkat dan martabat kemanusiaan, serta mendapat perlindungan dari kekerasan dan diskriminasi.

3. Konvensi tentang Hak-hak Anak Disetujui oleh Majelis Umum Perserikatan Bangsa Bangsa pada tanggal 20 Nopember 1989 Pasal 12 ayat (2). Untuk tujuan ini, maka anak terutama harus diberi kesempatan untuk didengar pendapatnya dalam persidangan-persidangan pengadilan dan administratif yang mempengaruhi anak itu, baik secara langsung, atau melalui suatu perwakilan atau badan yang tepat, dalam suatu cara yang sesuai dengan peraturan-peraturan prosedur hukum nasional. ${ }^{11}$

Menurut Staf lembaga bantuan anak mengemukan, para tahanan pra-persidangan dapat kehilangan pekerjaan mereka, terpaksa menelantarkan pendidikan mereka, dan tergusur dari tempat tinggal mereka. Mereka terpapar penyakit serta menderita gangguan fisik dan mental yang berlangsung lama setelah masa penahanan mereka berakhir. Keluarga mereka juga menderita akibat kehilangan pendapatan dan kesempatan untuk mengenyam pendidikan, termasuk dampak multi-generasi dimana anak-anak dari para tahanan mengalami penurunan pencapaian jenjang pendidikan serta pendapatan yang berkurang seumur hidupnya. Efek yang bergelombang ini tidak berhenti begitu saja, masyarakat dan Negara dimana berlangsung penggunaan penahanan pra-persidangan yang berlebihan juga harus menyerap dampak sosial ekonomi ini, inilah dampak yang selalu dialami oleh tahanan.

Dampak negatif dari penahanan prapersidangan yang berlebihan banyak akibat buruk yang diakibatkan oleh penggunaan penahanan pra-persidangan yang berlebihan secara global. Penahanan pra-persidangan yang berlebihan akan menghancurkan kehidupan individu, merusak keluarga dan menurunkan martabat masyarakat. ${ }^{12}$

\section{PENUTUP}

Berdasarkan dari uraian bab di atas maka dapat diambil beberapa kesimpulan antara lain:

1. Pertimbangan Hakim Pengadilan Tinggi dalam melakukan Penahanan terhadap anak yang melakukan tindak pidana dilakukan dengan sungguh-sungguh dan hakim untuk melakukan penahanan mempertimbangkan kepentingan anak dan atau kepentingan

\footnotetext{
${ }^{11}$ Rizanizarli. Akademisi Bidang Anak, Wawancara, Tanggal 01 april 2014

${ }^{12}$ Cut ani vaviyanti Staf Lembaga Bantuan Hukum Anak Wawancara Tanggal 13 Mai 2014
} 
masyarakat. Hakim Tinggi yang melakukan tindakan penahanan, harus terlebih dahulu mempertimbangkan dengan matang akibat dari tindakan penahanan, dari segi kepentingan anak, seperti pertumbuhan dan perkembangan anak baik fisik, mental maupun sosial. Seperti kita ketahui bersama anak memiliki jalan yang masih panjang untuk belajar kedepannya sehingga menjadi orang yang berguna, namun jika dalam dirinya sudah melekat sandangan orang yang pernah ditahan maka hal itu akan memupus masa depan anak tersebut. Mereka akan kehilangan masa-masa dimana mereka seharusnya mendapatkannya. Namun di sisi lain pertimbangan hakim tentang penahanan terhadap anak yang berhadapan dengan hukum antara lain:

a. Adanya kekhawatiran tersangka atau terdakwa melarikan diri

b. Merusak atau menghilangkan barang bukti atau mengulangi tindak pidana.

c. Dengan ditahannya tersangka masyarakat menjadi aman dan tentram

2. Dampak dari penahanan terhadap anak sebagai pelaku tindak pidana, maka dengan ditahan pengaruhnya cukub besar dan merugikan si anak, Akademisi bidang anak mengatakan, penahanan kepada anak yang bermasalah dengan hukum berdampak cukup besar terhadap anak, antara lain:

a. Anak akan mendapat ancaman kekerasan di tahanan baik oleh petugas atau tahanan lain.

b. Si anak akan rentan terhadap pelecehan seksual oleh tahanan lain, dan ada beberapa kasus anak disodomi oleh tahanan lainnya.

c. Terjadi transfer keterampilan kejahatan dari tahanan lama kepada tahanan baru. Akibatnya, saat keluar dari tahanan, anak akan berubah menjadi pelaku kriminal.

d. Dengan di tahan, anak tidak bisa melanjutkan pendidikan atau suramnya masa depannya si anak. 


\section{DAFTAR PUSTAKA}

Andi Hamzah, Pengantar Hukum Acara Pidana Indonesia, Ghalia Indonesia, Jakarta, 1984.

A. Hamzah \& Irdan Dahlan, Perbandingan KUHAP HIR dan Komentar, Ghalia Indonesia, Jakarta, 1984.

Barda Nawawi Arief, Perkembangan Sistem Pemidaan di Indonesia, Pustaka Magister, Semarang, 2007.

C.S.T Kansil dan Christine S.T. Kansil, Pokokpokok Hukum Pidana Untuk Tiap Orang, Pradnya Paramita, Jakarta, 2004.

Chairul Huda, Dari Tiada Pidana Tanpa Kesalahan Menuju Kepada Tiada Pertanggungjawaban Pidana Tanpa Kesalahan, Fajar Interpratama Offset, Jakarta, 2006.

Depdiknas, Kamus Besar Bahasa Indonesia, Balai Pustaka, Jakarta, 2002.

Kartini Kartono, Patologi Sosial 2 Kenakalan Remaja, Grafindo Persada, Jakarta, 2010.

Mardjono Reksodiputro, Hukum Pidana dan Batas-batas Toleransi Penegakan Hukum, Pidato Pengukuhan Guru Besar Fakultas Hukum Universitas Indonesai, Jakarta, 1994.

Maulana Hasan Wadong, Pengentar Advokasi Dan Perlindungan Anak, Jakarta, PT Grasindo, 2000.

Maulana Hasan Wadong, Pengentar Advokasi Dan Perlindungan Anak, Jakarta, PT Grasindo, 2000.
M. Yahya Harahap, Pembahasan pemasalahan dan Penerapan KUHAP, Sinar Grafika, Jakarta, 2003.

M. Yahya Harahap, pembahasan permasalahan dan penerapan KUHAP, Sinar Grafika, jakarta, 2006.

Made Sadhi Astuti, Selayang Pandang Anak Sebagai Korban dan Pelaku Tindak Pidana, Arena Hukum, Malang. 1997

Marlina, Peradilan Pidana Anak di Indonesia: Pengembangan Konsep Diversi dan Restrorative Justice, Refika Aditama, Medan, 2009.

Ninik Widiyanti -Panji Anaroga, Perkembangan Kejahatan dan Masalahnya ditinjua dari segi kriminologi dan sosial, Pradnya Paramita, Jakarta, 1987

Sudibyo Triatmojo, Pelaksanaan Penahanan dan Kemungkinan yang Ada dalam KUHAP, Alumni, Bandung, 1982.

Sri Widowati Soekanto, Anak dan Wanita Dalam Hukum, LP 3 ES, Jakarta, 1984

Shanty Delllyana, Wanita Dan Anak Di Mata Hukum, Yogyakarta, Liberty, 1990.

Sudarsono, Kenakalan Remaja, Rineka Cipta, Jakarta, 1991

Sumitro, Inti Hukum Acara Pidana, Sebelas Maret University Press, Surakarta, 1994.

J.E Sahetapy, "Hukum dalam Konteks Sosial Politik dan Budaya”. 11 Analisis, Tahun XXII No. 1 Januari - Februari 1993.

KUHAP ( Kitab Undang-Undang Hukum Acara Pidana ) 
UU Nomor 8 Tahun 1981 ( Kitab Undangundang Hukum Acara Pidana Lembaran Negara )

Undang-Undang No.3 Tahun 1997, tentang Pengadilan Anak

Undang-undang Nomor 11 Tahun 2009 (Tentang Pokok-pokok Kekuasaan Kehakiman )

Undang-Undang Republik Indonesia Nomor 11 Tahun 2012 Tentang Sietem Peradilan Pidana Anak.

Wahyu Afandi, Hakim Dan Hukum Dalam Praktek, Alumni Bandung, Bandung, 1978.

Wagiati Sutedjo, Hukum Pidana Anak, PT.

Raflika Aditama, Bandung, 2006 